\title{
Effects of Quercetin Supplementation on Lipid and Protein Metabolism after Classic Boxing Training
}

\author{
Nevzat Demirci ${ }^{1}$, Mehmet Akif Ziyagil ${ }^{1}$ \\ ${ }^{1}$ Mersin University; School of Physical Education Sports, Department of Coaching Education, Çiftlikköy Kampusu, \\ 33343, Yenişehir, Mersin, Turkey \\ Correspondence: Nevzat Demirci, Mersin University; School of Physical Education Sports, Department of Coaching \\ Education, Çiftlikköy Kampusu, 33343, Yenişehir, Mersin, Turkey.
}

Received: February 3, 2017

Accepted: February 28, 2017 Online Published: March 3, 2017

doi:10.11114/jets.v5i4.2193

URL: https://doi.org/10.11114/jets.v5i4.2193

\begin{abstract}
The metabolic fitness (MF) is a component of athletes' physical conditioning. This study aims to investigate the effects of quercetin supplementation on Turkish Junior athletes' lipid and protein metabolism relating to MF after one month classic boxing training. Totally 20 voluntary junior male athletes were separated into two equal groups as the experimental group (EG) and control group (CG). The participants were supplemented with $500 \mathrm{mg}$ quercetin fifteen minutes before each workout in one month boxing training program. Blood samples during pre and post training were taken from athletes in order to determine metabolic fitness related parameters. Lipid profile contains low-density lipoprotein cholesterol (LDL-C), high-density lipoprotein cholesterol (HDL-C), trigliserid (TG), total cholesterol (TC) variables while protein metabolism includes the albumin, total protein, direct bilirubin and total bilirubin parameters. The Mann Whitney $\mathrm{U}$ analyzes were used for comparison of the means between experimental and control groups during pre and posttest and between pre and post test results in experimental and control groups. This study showed that EG had a similar physical characteristic with CG. There were significant decrease in TC and LDL-C and an increase in HDL-C in EG while there was only significant increase in HDL-C of in controls. A significant difference of HDL-C was observed between EG and CG during pretest. In other side, TC and LDL-C and HDL-C were significantly differentiated between EG and CG during posttest. Conclusion: it can be concluded that quercetin plays an important role on lipid metabolism not protein.
\end{abstract}

Keywords: quercetin, lipid profile, protein metabolism, metabolic fitness, boxing

\section{Introduction}

The free radical production is accelerated in parallel with the increase in oxygen consumption depending on the intensity of the exercise. Quercetin has similar effect with exercise in the acceleration of energy metabolism (Palmer et al., 2003; Chen et al., 2005). Cardiovascular disease is one of the most important health problems in the world and the most common symptom of this problem is atherosclerosis. Low-density lipoprotein cholesterol (LDL-C) and high-density lipoprotein cholesterol (HDL-C) are often associated with diet-induced atherosclerosis (Made Harumi et al., 2015).

The control of lipid profile, obesity and overweight risk factors is one of the most important strategies for improving human health and any disorder in these parameters can lead to the development of cardiovascular diseases (Hopper et al., 2001). Some studies suggest that regular intensive exercise decreases lipid profile, in other words total cholesterol, triglycerides and LDL-C, while increases HDL-C (Crimi et al., 2009; Zabet et al., 2010). Conversely, some other studies have reported that there are no changes in these parameters following the exercises (Davis et al., 1992; Mousavizadeh et al., 2009).

Quercetin is a flavonoid found in many plants and is a strong antioxidant due to its ability to sweep free radicals (Kelly, 2011; Nam et al., 2016). Quercetin appears to play an important role in human health and has beneficial effects in preventing human diseases. Quercetin is effective on multiple biological pathways, clearing free radicals as antioxidants and leading to oxidation of endothelial cells, extracellular collagen matrix and plasma lipids (TC, LDL-C) and consequently reducing the probability of developing atherosclerosis (Larson et al., 2012).

In the study of Lee et al. (2011), quercetin supplementation in healthy smokers for 10 weeks leads to a decrease in TC 
and LDL-C while an increase HDL-C. Also Talirevic and Jelena (2012) administered quercetin supplementation to patients with dyslipidemia for 2 months and they obtained similar results. Yi et al. (2011) reported that quercetin supplementation to 15 healthy subjects lowered their LDL-C levels and inhibited atherosclerosis. Similarly, Askari et al. (2013) reported that the administration of $500 \mathrm{mg}$ quercetin in 60 healthy males for 8 weeks reduced significantly the LDL-C concentration while no significant change HDL-C lipoprotein level. Conversely, Brüll et al (2015) examined the effect of quercetin supplementation on 68 obese subjects for 6 weeks and they found that there was no significant effect on TC, LDL-C and HDL-C levels.

Intensive training and competition in boxing needs high level of metabolic fitness is the base of athlete's physical conditioning. This capacity makes possible the athlete to get fast recovery and energy regeneration after workouts and competitions. Quercetin can play an important role in complex oxidative functions involving the oxygen binding to a biochemical substance during physiological reactions. In addition, quercetin is considered to be an important antioxidant in the extracellular fluid and it has been shown to effectively oxidized superoxide, hydrogen peroxide, lipid peroxidation and also protein carbonyl compound (Selvakumar et al. 2013). This study aims to investigate the effects of quercetin supplementation on Turkish Junior athletes' lipid and protein metabolism relating to MF after one month classic boxing training.

\section{Material and Methods}

\subsection{Participants}

Data were collected from 20 voluntary junior male athletes separating into two equal groups as the experimental group (EG) and control group (CG). The participants were supplemented with $500 \mathrm{mg}$ quercetin fifteen minutes before each workout in one month boxing training program. The mean values of participants were $18.95 \pm 1$ years for age, $167.35 \pm 2.81 \mathrm{~cm}$ for body height, $62.85 \pm 0.99 \mathrm{~kg}$ for body weight and $22.46 \pm 0.92 \mathrm{for}$ BMI, respectively. All the details of the study were explained to the subjects and the study was approved by the ethics commission of Medical Faculty at the Kafkas University and it was conducted in line with the relevant directive specified in Helsinki Declaration.

\subsection{Exercise Protocol (Classic Boxing Training)}

Control and experimental group an exercise program of two hours applied to the athletes three times a week for one month. Athletes performed classic boxing training after 20 minutes warm up including jogging, stretching and calisthenics exercises. This workout was consisted of rope skipping, shadow boxing, foot working and technical exercises with partners. It was ensured that the participants did not take any medicine within 15 days before the test, which may affect antioxidant defense, and their diets were standardized. Quercetin group was supplemented with 500 mg Quercetin 15 minutes before daily training for 30 days.

\subsection{Blood Sampling and Assessment}

Blood samples during pre and post training were taken from athletes in order to determine metabolic fitness related parameters. In the study, blood samples were taken from all athletes before and 30 days after the training.

Lipid profile contains HDL-C, LDL-C, TG, TC variables while protein metabolism includes the albumin, total protein, direct bilirubin and total bilirubin parameters. All data were collected in the Medical Faculty laboratory at Kafkas University. Blood samples were withdrawn into heparinized tubes from a cubital vein after overnight fasting and immediately stored in ice. Plasma was separated from cells by centrifugation at $4000 \mathrm{rpm}$ for 15 minutes and the plasma samples were stored at $-20^{\circ} \mathrm{C}$ until analysis. All parameters was analyzed by COBAS c311 system (Roche Diagnostics, Germany)

\subsection{Statistical Analyzes}

All statistical analyses were performed by SPSS version 13.0. Results of descriptive statistics in this study are presented as mean, standard deviation, and minimum and maximum values. The Mann Whitney $\mathrm{U}$ analyzes were used for comparison of the means between experimental and control groups during pre and posttest and between pre and post test results in experimental and control groups.

\section{Results}

There was no significant difference between the groups in terms of physical characteristics (p>0.05*) (Table 1). The results of this study showed that pre and post test results in the control group was only significantly differentiated in HDL-C levels after exercise with respect to the lipid profile after quercetin supplementation $(\mathrm{P}<0.01)$ (Table 2). No difference was observed in protein metabolism in control group. 
Table1. Comparison of physical properties between experimental and control groups

\begin{tabular}{|c|c|c|c|c|c|c|}
\hline & & $\mathrm{N}$ & M. & SD. & Mann Whitney U & Asymp. Sig. \\
\hline \multirow{3}{*}{ Age (Years) } & Experimental & 10 & 18,90 & 0,99 & \multirow{3}{*}{47,500} & \multirow{3}{*}{, 841} \\
\hline & Control & 10 & 19,00 & 1,05 & & \\
\hline & Total & 20 & 18,95 & 1,00 & & \\
\hline \multirow{3}{*}{$\begin{array}{l}\text { Body Height } \\
\text { (cm) }\end{array}$} & Experimental & 10 & 167,20 & 3,01 & \multirow{3}{*}{48,500} & \multirow{3}{*}{,908 } \\
\hline & Control & 10 & 167,50 & 2,76 & & \\
\hline & Total & 20 & 167,35 & 2,81 & & \\
\hline \multirow{3}{*}{$\begin{array}{l}\text { Body Weight } \\
(\mathrm{kg})\end{array}$} & Experimental & 10 & 63,00 & 1,05 & \multirow{3}{*}{40,500} & \multirow{3}{*}{,453 } \\
\hline & Control & 10 & 62,70 & 0,95 & & \\
\hline & Total & 20 & 62,85 & 0,99 & & \\
\hline \multirow{3}{*}{$\begin{array}{c}\text { Body Mass } \\
\text { İndex } \\
\text { (BMI) }\end{array}$} & Experimental & 10 & 22,56 & 1,06 & \multirow{3}{*}{45,500} & \multirow{3}{*}{, 733} \\
\hline & Control & 10 & 22,37 & 0,80 & & \\
\hline & Total & 20 & 22,46 & 0,92 & & \\
\hline
\end{tabular}

On the other hand, quercetin supplementation decreased significantly the TC and LDL-C $(\mathrm{P}<0.01)$ and increased the HDL-C levels in the experimental group while there was no significant change in the means of control group according to the pre and posttest results $(\mathrm{P}<0.05)$. Conversely, the small differences in the levels of protein metabolism between two groups were not statistically significant depending on quercetin supplementation ( $p>0.05)$ (Table 2).

Table 2. Comparison of lipid profiles, protein metabolism between pre and posttest in experimental and control groups

\begin{tabular}{|c|c|c|c|c|c|c|c|c|c|c|}
\hline \multirow[b]{2}{*}{ Variables } & \multirow[b]{2}{*}{ Group } & \multirow[b]{2}{*}{$\mathrm{N}$} & \multicolumn{4}{|c|}{ EXPERIMENTAL GROUP } & \multicolumn{4}{|c|}{ CONTROL GROUP } \\
\hline & & & M & SD & $\begin{array}{l}\text { MW } \\
\text { U Test }\end{array}$ & $\begin{array}{l}\text { Asymp. } \\
\text { Sig }\end{array}$ & M & SD & $\begin{array}{l}\text { MW } \\
\text { U Test }\end{array}$ & $\begin{array}{l}\text { Asymp. } \\
\text { Sig }\end{array}$ \\
\hline \multirow{3}{*}{$\begin{array}{c}\text { Total } \\
\text { Bilirubin } \mathrm{mg} / \mathrm{dL}\end{array}$} & Pre test & 10 & 0,94 & 0,39 & & & 0,74 & 0,20 & & \\
\hline & Post test & 10 & 0,87 & 0,31 & 46,000 & ,761 & 0,74 & 0,20 & 48,500 & ,910 \\
\hline & Total & 20 & 0,90 & 0,34 & & & 0,74 & 0,19 & & \\
\hline \multirow{4}{*}{$\begin{array}{c}\text { Direct } \\
\text { Bilirubin } \mathrm{mg} / \mathrm{dL}\end{array}$} & Pre test & 10 & 0,16 & 0,05 & & & 0,13 & 0,03 & & \\
\hline & Post test & 10 & 0,14 & 0,05 & 40,000 &, 447 & 0,12 & 0,03 & 43,500 & ,620 \\
\hline & Total & 20 & 0,15 & 0,05 & & & 0,13 & 0,03 & & \\
\hline & Pre test & 10 & 7,43 & 0,21 & & & 7,28 & 0,47 & & \\
\hline \multirow[t]{2}{*}{ Total protein $\mathrm{g} / \mathrm{dL}$} & Post test & 10 & 7,35 & 0,11 & 37,500 & ,336 & 7,25 & 0,39 & 49,000 & ,939 \\
\hline & Total & 20 & 7,39 & 0,17 & & & 7,27 & 0,42 & & \\
\hline \multirow{3}{*}{$\begin{array}{l}\text { Albumin } \\
\text { g/dL }\end{array}$} & Pre test & 10 & 4,65 & 0,29 & & & 4,71 & 0,25 & & \\
\hline & Post test & 10 & 4,52 & 0,35 & 38,000 & ,360 & 4,67 & 0,24 & 44,500 & ,674 \\
\hline & Total & 20 & 4,59 & 0,32 & & & 4,69 & 0,24 & & \\
\hline \multirow{3}{*}{$\begin{array}{c}\text { Total } \\
\text { Cholesterol mg/dL }\end{array}$} & Pre test & 10 & 140,80 & 24,62 & & & 149,30 & 16,76 & & \\
\hline & Post test & 10 & 108,90 & 10,95 & 6,000 &, $001 * *$ & 148,70 & 14,87 & 46,000 &, 762 \\
\hline & Total & 20 & 124,85 & 24,73 & & & 149,00 & 15,42 & & \\
\hline \multirow{3}{*}{$\begin{array}{l}\text { HDL-C } \\
\mathrm{mg} / \mathrm{dL}\end{array}$} & Pre test & 10 & 46,10 & 7,46 & & & 40,20 & 4,47 & & \\
\hline & Post test & 10 & 55,10 & 7,40 & 18,500 &, $016^{*}$ & 46,50 & 5,38 & 16,000 &, $009 * *$ \\
\hline & Total & 20 & 50,60 & 8,58 & & & 43,35 & 5,80 & & \\
\hline \multirow{3}{*}{$\begin{array}{l}\text { LDL-C } \\
\mathrm{mg} / \mathrm{dL}\end{array}$} & Pre test & 10 & 80,40 & 13,01 & & & 90,20 & 17,09 & & \\
\hline & Post test & 10 & 64,10 & 6,31 & 13,500 &, $006^{* *}$ & 82,80 & 15,49 & 32,500 & , 185 \\
\hline & Total & 20 & 72,25 & 13,00 & & & 86,50 & 16,32 & & \\
\hline \multirow{3}{*}{ Trigliserid mg/dL } & Pre test & 10 & 59,70 & 18,25 & & & 65,70 & 14,90 & & \\
\hline & Post test & 10 & 54,50 & 13,83 & 41,000 & ,491 & 60,90 & 12,17 & 41,000 & ,492 \\
\hline & Total & 20 & 57,10 & 15,99 & & & 63,30 & 13,47 & & \\
\hline
\end{tabular}

* Significant difference at $\mathrm{p}<.05$ level. ** Significant difference at $\mathrm{p}<.01$ level. Mann Whitney U Test=MW U Test

There was only a significant difference $(\mathrm{P}<0.05)$ in the pre-exercise HDL-C levels between experimental and control group in the comparison of the lipid profile and protein metabolism results (Table 3). On the other hand, significant decreases in TC and LDL-C ( $\mathrm{P}<0.01)$ and increase in HDL-C levels were observed in the experimental group between pre- and posttest results in both groups $(\mathrm{P}<0.05)$ while no significant difference in the control group. Pre and posttest 
levels of protein metabolism were not differentiated between experimental and control group (p>0.05) (Table 3).

Table 3. Comparison of lipid profile and protein metabolism between experimental and control groups during pretest and posttest

\begin{tabular}{|c|c|c|c|c|c|c|c|c|c|c|}
\hline \multirow[b]{2}{*}{ Variables } & \multirow[b]{2}{*}{ Group } & & \multicolumn{4}{|c|}{ PRE TEST } & \multicolumn{4}{|c|}{ POST TEST } \\
\hline & & $\mathrm{N}$ & M & SD & $\begin{array}{c}\text { MW } \\
\text { U Test }\end{array}$ & $\begin{array}{c}\text { Asymp. } \\
\text { Sig }\end{array}$ & M & SD & $\begin{array}{c}\text { MW } \\
\text { U Test }\end{array}$ & $\begin{array}{c}\text { Asymp. } \\
\text { Sig }\end{array}$ \\
\hline \multirow{3}{*}{$\begin{array}{c}\text { Total } \\
\text { Bilirubin } \mathrm{mg} / \mathrm{dL}\end{array}$} & Experimental & 10 & 0,94 & 0,39 & & & 0,87 & 0,31 & & \\
\hline & Control & 10 & 0,74 & 0,20 & 33,500 & ,212 & 0,74 & 0,20 & 39,000 & ,405 \\
\hline & Total & 20 & 0,84 & 0,32 & & & 0,80 & 0,26 & & \\
\hline \multirow{3}{*}{$\begin{array}{c}\text { Direct } \\
\text { Bilirubin } \mathrm{mg} / \mathrm{dL}\end{array}$} & Experimental & 10 & 0,16 & 0,05 & & & 0,14 & 0,05 & & \\
\hline & Control & 10 & 0,13 & 0,03 & 34,500 & ,239 & 0,12 & 0,03 & 40,000 & ,444 \\
\hline & Total & 20 & 0,14 & 0,04 & & & 0,13 & 0,04 & & \\
\hline \multirow{3}{*}{$\begin{array}{l}\text { Total protein } \\
\text { g/dL }\end{array}$} & Experimental & 10 & 7,43 & 0,21 & & & 7,35 & 0,11 & & \\
\hline & Control & 10 & 7,28 & 0,47 & 38,000 & ,361 & 7,25 & 0,39 & 40,000 & ,443 \\
\hline & Total & 20 & 7,36 & 0,36 & & & 7,30 & 0,28 & & \\
\hline \multirow{3}{*}{$\begin{array}{l}\text { Albumin } \\
\text { g/dL }\end{array}$} & Experimental & 10 & 4,65 & 0,29 & & & 4,52 & 0,35 & & \\
\hline & Control & 10 & 4,71 & 0,25 & 46,000 & ,760 & 4,67 & 0,24 & 36,500 & ,304 \\
\hline & Total & 20 & 4,68 & 0,26 & & & 4,60 & 0,30 & & \\
\hline \multirow{3}{*}{$\begin{array}{c}\text { Total } \\
\text { Cholesterol } \\
\text { mg/dL }\end{array}$} & Experimental & 10 & 140,80 & 24,62 & & & 108,90 & 10,95 & & \\
\hline & Control & 10 & 149,30 & 16,76 & 32,500 & , 186 & 148,70 & 14,87 & 1,500 &, $000 * *$ \\
\hline & Total & 20 & 145,05 & 20,95 & & & 128,80 & 24,05 & & \\
\hline \multirow{3}{*}{$\begin{array}{l}\text { HDL-C } \\
\mathrm{mg} / \mathrm{dL}\end{array}$} & Experimental & 10 & 46,10 & 7,46 & & & 55,10 & 7,40 & & \\
\hline & Control & 10 & 40,20 & 4,47 & 23,500 &, $042 *$ & 46,50 & 5,38 & 16,500 &, $010 * *$ \\
\hline & Total & 20 & 43,15 & 6,71 & & & 50,80 & 7,69 & & \\
\hline \multirow{3}{*}{$\begin{array}{l}\text { LDL-C } \\
\mathrm{mg} / \mathrm{dL}\end{array}$} & Experimental & 10 & 80,40 & 13,01 & & & 64,10 & 6,31 & & \\
\hline & Control & 10 & 90,20 & 17,09 & 28,000 & ,096 & 82,80 & 15,49 & 12,500 &, $004 * *$ \\
\hline & Total & 20 & 85,30 & 15,61 & & & 73,45 & 14,99 & & \\
\hline \multirow{3}{*}{$\begin{array}{l}\text { Trigliserid } \\
\mathrm{mg} / \mathrm{dL}\end{array}$} & Experimental & 10 & 59,70 & 18,25 & & & 54,50 & 13,83 & & \\
\hline & Control & 10 & 65,70 & 14,90 & 34,500 & ,239 & 60,90 & 12,17 & 30,500 & ,138 \\
\hline & Total & 20 & 62,70 & 16,51 & & & 57,70 & 13,10 & & \\
\hline
\end{tabular}

* significant difference at $\mathrm{p}<.05$ level. ** significant difference at $\mathrm{p}<.01$ level. Mann Whitney U Test=MW U Test

\section{Discussion}

Many studies focusing the effect of exercise on lipids and protein metabolism showed that intensive exercise changes the lipid and protein profiles of athletes depending on training variables including intensity, time, frequency and duration of exercise. It is observed that exercise leads to a decrease in TC, LDL-C, and an increase in HDL-C levels. This effect of exercise on serum lipid levels result in decreasing cardiovascular risk factors (La Monte et al.2001; Crimi et al., 2009; Zabet et al., 2010). Quercetin, on the other hand, is regarded as an agent that increases mental and physical performance during intense exercise and reduces the risk of infection due to its biological properties. Quercetin is not only beneficial with its anti-inflammatory effect but also for its antioxidant and psych stimulant effects as well as its stimulatory effect on mitochondrial biogenesis and Immunity enhancing effect on health (Cureton et al.2009). Thus the aim of this study is to investigate the effects of quercetin supplementation on Turkish Junior athletes' lipid and protein metabolism indicating their metabolic fitness level after one month classic boxing training.

According to the results of this study, pre and post test results in the control group was only significantly differentiated in HDL-C levels after exercise with respect to the lipid profile after quercetin supplementation (Table 2). In experimental group, quercetin had a significant decreasing effect on the TC and LDL-C and increasing effect on the HDL-C levels. Classic boxing training plus quercetin supplementation had a strong effect on lipid profile compare to controls. It was well established that quercetin had the antioxidant effect on free radicals and regulatory effect on lipid profile. Also, it appears to be the most effective flavonoid in protecting the body against reactive oxygen metabolites (Huy et al. 2008).

In the study of Prabu et al (2010), it was determined that the supplementation of $50 \mathrm{mg}$ quercetin on rats for 4 weeks resulted in a significant increase in HDL-C and a decrease in LDL-C. Similarly; Lee and et al (2011) found that the supplying of quercetin (100 mg / day) to healthy male smokers for 10 weeks significantly reduced the TC and LDL-C 
concentration while a significant increase in serum HDL-C. These results had the similarities with the study of Prabu et al (2010) and Lee and et al (2011). Conversely, Brüll et al (2015) examined the effect of quercetin supplementation on 68 obese subjects for 6 weeks and they found that there was no significant effect on TC, LDL-C and HDL-C levels. Therefore, it can be evaluated that the implementation quercetin plus exercise had a protective effect on cell integrity while reducing oxidative stress.

Exercise induced a severe oxidative stress resulting in the depletion of plasma and tissue antioxidants have been shown to be an important inhibitor of cardiovascular disease (Dietz et al. 2012; Heckman and McKelvie 2008). Quercetin is particularly anti-carcinogenic and anti-atherosclerotic with its inhibiting the bioactivation process of carcinogens and inhibiting LDL oxidation (Nijveldt et al. 2001). It appears from these studies that the combination of exercise and quercetin supplementation may produce greater cardiovascular benefits than exercise alone.

Results of this study showed that the comparison of experimental and control groups during pretest were only significantly differentiated in HDL-C levels with respect to the lipid profile before quercetin supplementation. During posttest, differences between experimental and control was observed not only in HDL-C, but also LDL-C and TC (Table 3). Differences between experimental and control groups approved the strong effect of exercise plus quercetin effect on lipid metabolism. In an animal study, Harumi et al (2015) investigated the protective effect of quercetin by separating 20 male rats into 4 groups. was investigated by feeding on a high fat diet for 4 weeks. All treatment groups showed that quercetin had a positive effect on the prevention of hyper-cholesterolemia by the inhibiting increased LDL and the preventing decreased in HDL. These results were in accordance with the findings of our study. Several mechanisms have been described and attributed to the anti-atherogenic effects of exercise and quercetin. It is commonly accepted that moderate exercise is an important component of a healthy lifestyle that helps to prevent or delay the onset of coronary artery disease (Garelnabi et al. 2012; Fernandes-Silva et al. 2012).

On the other hand Quercetin has been shown to act through various mechanisms mainly linked to reducing the inflammation and oxidative stress levels which are responsible for the atherosclerotic pathogenesis. Earlier studies have shown that quercetin significantly inhibit in vitro LDL oxidation, and also protects macrophages from oxidized low-density lipoprotein induced apoptosis (Naderi et al. 2003; Yang et al. 2012). Similarly, it is well known that HDL-C levels play a protective role in cardiovascular disease, while elevated LDL cholesterol levels increase the risk of developing atherosclerosis (Silbernagel et al., 2013, Warnholtz et al., 2001). The formation of atherosclerosis depends on the blood lipid level. Hypercholesterolemia is an important risk factor for atherosclerosis, even in the absence of other factors. The main component of serum cholesterol associated with increased risk of atherosclerosis is LDL-C. Therefore high HDL-C levels correlate with reduced risk (Kumar et al., 2010).

In conclusion, the combination of classic boxing training and quercetin supplementation resulted in significant decreases in TC and LDL-C values and significant increases in HDL-C values in the experimental group compared to the control group while there was only an increase in HDL-C level of the control group after exercise. This means that quercetin plays an important role on lipid metabolism not protein. Thus quercetin intake plus exercise may lead to reduce the cardiovascular risk factors including hypercholesterolemia and lipid level by increasing metabolic fitness level in athletes.

\section{Conflicts of Interest}

There isn't any conflict of interest to be declared regarding the manuscript.

\section{References}

Askari, G., Hajishafiee, M., Ghiasvand, R., Hariri, M., Darvishi, L., Ghassemi, S. et al., (2013). Quercetin and vitamin C supplementation: effects on lipid profile and muscle damage in male athletes. Int J Prev Med., Apr., 4(Suppl 1), 58-62.

Brüll, V., Burak, C., Stoffel-Wagner, B., Wolffram, S., Nickenig, G., Müller, C. et al., (2016). Acute intake of quercetin from onion skin extract does not influence postprandial blood pressure and endothelial function in overweight-to-obese adults with hypertension: a randomized, double-blind, placebo-controlled, crossover trial. Eur. J. Nutr., 1-11. https://doi.org/10.1007/s00394-016-1185-1

Chen, J. C., Ho, F. M., Pei-Dawn, L. C., Chen, C. P., Jeng, K. C., Hsu, H. B. et al., (2005). Inhibition of iNOS gene expression by quercetin is mediated by the inhibition of IkappaB kinase, nuclear factor-kappa B and STAT1, and depends on heme oxygenase-1 induction in mouse BV-2 microglia. Eur. J. Pharmacol., 521(1-3), 9-20. https://doi.org/10.1016/j.ejphar.2005.08.005

Crimi, E., Ignarro, L. J., Cacciatore, F., \& Napoli, C. (2009). Mechanisms by which exercise training benefits patients with heart failure. Nature reviews Cardiology, 6(4), 292-300. https://doi.org/10.1038/nrcardio.2009.8 
Cureton, K. J., Tomporowski, P. D., Singhal, A., Pasley, J. D., Bigelman, K. A., Lambourne, K. et al (2009). Dietary quercetin supplementation is not ergogenic in untrained men. J. Appl. Physiol., 107(4), 1095-1104. https://doi.org/10.1152/japplphysiol.00234.2009

Davis, P. G., Bartoli, W. P., \& Durstine, J. L. (1992). Effects of acute exercise intensity on plasma lipids and apolipoproteins in trained runners. Journal of applied physiology (Bethesda, Md : 1985), 72(3), 914-919.

Dietz, P., Hoffmann, S., Lachtermann, E., \& Simon, P. (2012). Influence of exclusive resistance training on body composition and cardiovascular risk factors in overweight or obese children: a systematic review. Obes Facts, 5(4), 546-560. https://doi.org/10.1159/000341560

Fernandes-Silva, M. M., Carvalho, V. O., Guimarães, G. V., Bacal, F., \& Bocchi, E. A. (2012). Physical exercise and microRNAs: new frontiers in heart failure. Arq. Bras. Cardiol., 98(5), 459-466. https://doi.org/10.1590/S0066-782X2012000500012

Garelnabi, M., Veledar, E., White-Welkley, J., Santanam, N., Abramson, J., Weintraub, W. et al (2012). Vitamin E differentially affects short term exercise induced changes in oxidative stress, lipids, and inflammatory markers. Nutr. Metab. Cardiovasc. Dis., 22(10), 907-913. https://doi.org/10.1016/j.numecd.2011.03.002

Heckman, G. A., \& McKelvie, R. S. (2008). Cardiovascular aging and exercise in healthy older adults. Clin. J. Sport. Med., 18(6), 479-485. https://doi.org/10.1097/JSM.0b013e3181865f03

Hopper, C. A., Gruber, M. B., Munoz, K. D., MacConnie, S. E., Pfingston, Y. M., \& Nguyen, K. (2001). Relationship of blood cholesterol to body composition, physical fitness, and dietary intake measures in third-grade children and their parents. Research Quarterly for Exercise and Sport, 72(2), 182-188.

https://doi.org/10.1080/02701367.2001.10608948

Kelly, G. S. (2011). Quercetin. Monograph. Altern. Med. Rev., 16, 172-194.

Kumar, V., Abbas, A. K., \& Aster, J. C. (2010). Robbin and Cotran Pathology Basic of Disease, 8th ed, Philadhelpia: Saunders Elsevier.

La Monte, M. J., Durstine, J. L., Addy, C. L., Irwin, M. L., \& Ainsworth, B. E. (2001). Physical activity, physical fitness, and Framingham 10-year risk score: cross-cultural activity participation study. J. Cardiopulm. Rehabil., 21, 63. https://doi.org/10.1097/00008483-200103000-00001

Larson, A. J., Symons, J. D., \& Jalili, T. (2012). Therapeutic potential of quercetin to decrease blood pressure: review of efficacy and mechanisms. Adv. Nutr., 3, 39-46. https://doi.org/10.3945/an.111.001271

Lee, K. H., Park, E., Lee, H. J., Kim, M. O., Cha, Y. J., Kim, J. M. et al., (2011). Effects of daily quercetin-rich supplementation on cardiometabolic risks in male smokers. Nutr. Res. Pract., 5(1), 28-33. https://doi.org/10.4162/nrp.2011.5.1.28

Made, H. P., Trisna, G., Nyoman, O. P. G., Deby, A. R., Khrisnawati, A. A. A. P., \& Farmawati, A. (2015). Quercetin And Curcumin Prevent Decreasing Of LDL-Cholesterol And Increasing Of HDL-Cholesterol In High Fat Diet Rats. Media Farmasi, 12(2), 225-232.

Mousavizadeh, M. S., Ebrahimi, K., \& Nikbakht, H. (2009). Effect of one period of selective aerobic training on hematological indexes of girls. Sci. J. Iran Blood Transfus. Organ., 6(3), 227-231.

Naderi, G. A., Asgary, S., Sarraf-Zadegan, N., \& Shirvany, H. (2003). Anti-oxidant effect of flavonoids on the susceptibility of LDL oxidation. Mol. Cell Biochem., 246(1-2), 193-196. https://doi.org/10.1023/A:1023483223842

Nam, J. S., Sharma, A. R., Nguyen, L. T., Chakraborty, C., Sharma, G., \& Lee, S. S. (2016). Application of bioactive quercetin in oncotherapy: from nutrition to nanomedicine. Molecules; 21, E108. https://doi.org/10.3390/molecules21010108

Nijveldt, R. J., van Nood, E., van Hoorn, D. E., Boelens, P. G., van Norren, K., \& van Leeuwen, P. A. (2001). Flavonoids: a review of probable mechanisms of action and potential applications. Am. J. Clin. Nutr., 74(4), 418-425.

Palmer, F. M., Nieman, D. C., Henson, D. A., Mcanulty, S. R., Mcanulty, L., Swick, N. S. et al (2003). İnfluence of vitamin $\mathrm{c}$ supplementation on oxidative and salivary iga changes following an ultramarathon. Eur. J. Appl. Physiol., 89, 100-107. https://doi.org/10.1007/s00421-002-0756-4

Pham-Huy, H. H., \& Pham-Huy, C. (2008). Free radicals, antioxidants in disease and health. International Journal of Biomedical Science, 4(2), 89-96. 
Prabu, S. M., Shagirtha, K., \& Renugadevi, J. (2010). Amelioration of cadmium-induced oxidative stress, impairment in lipids and plasma lipoproteins by the combined treatment with quercetin and $\alpha$-tocopherol in rats. J. Food Sci., 75, T132-140. https://doi.org/10.1111/j.1750-3841.2010.01757.x

Selvakumar, K., Bavithra, S., Suganya, S., Bhat, A. F., Krishnamoorthy, G., \& Arunakaran, J. (2013). Effect of Quercetin on Haematobiochemical and Histological Changes in the Liver of Polychlorined Biphenyls-Induced Adult Male Wistar Rats. Journal of Biomarkers, 12, 1-12. https://doi.org/10.1155/2013/960125

Silbernagel, G., Schöttker, B., Appelbaum, S., Scharnagl, H. , Kleber, M. E., \& Grammer, T. B. (2013). High-density lipoprotein cholesterol, coronary artery disease, and cardiovascular mortality. Eur. Heart J., 34(46), 3563-3571. https://doi.org/10.1093/eurheartj/eht343

Talirevic, E., \& Jelena, S. (2012). Quercetin in the treatment of dyslipidemia. Med Arh., 66(2), 87-88. https://doi.org/10.5455/medarh.2012.66.87-88

Warnholtz, A., Mollnau, H., Oelze, M., Wendt, M., \& Munzel, T. (2001). Antioxidants and endothelial dysfunction in hyperlipidemia, Curr Hypertens Rep., 3, 53-60. https://doi.org/10.1007/s11906-001-0081-z

Yang, N., Liu, Q., Zhang, Y., Jiao, P., Zong, C., \& Qin, S. (2012). Quercetin protects macrophages from oxidized low-density lipoproteininduced apoptosis by inhibiting the endoplasmic reticulum stress-C/EBP homologous protein pathway. Exp. Biol. Med. (Maywood), 237(7), 822-831. https://doi.org/10.1258/ebm.2012.012027

Yi, L., Jin, X., Chen, C. Y., Fu, Y. J., Zhang, T., Chang, H., et al. (2011). Chemical Structures of 4-Oxo-Flavonoids in Relation to Inhibition of Oxidized Low-Density Lipoprotein (LDL)-Induced Vascular Endothelial Dysfunction. Int. J. Mol. Sci., 12, 5471-5489. https://doi.org/10.3390/ijms12095471

Zabet, A., Souri, R., \& Salehian, O. (2010). The Effect of Aerobic Activity on Cardiovascular Markers (ICAM-1, VCAM-1 and Lipid Profile) in Sendentary Obese Men. Journal of Sport Biosciences, 2(5), 19-35.

\section{Copyrights}

Copyright for this article is retained by the author(s), with first publication rights granted to the journal.

This is an open-access article distributed under the terms and conditions of the Creative Commons Attribution license which permits unrestricted use, distribution, and reproduction in any medium, provided the original work is properly cited. 